\title{
Assessment of the Pharmacological Activities of Ardisia solanacea Roxb: An Ethnomedicinal Plant used in Bangladesh
}

\author{
Mohammad Rashedul Islam, Nawreen Monir Proma, Jannatul Naima, Md. Giash Uddin, \\ Syeda Rubaiya Afrin and Mohammed Kamrul Hossain
}

\author{
Department of Pharmacy, Faculty of Biological Sciences, University of Chittagong, Chittagong-4331, \\ Bangladesh
}

\begin{abstract}
:
Objective: This study aims to uncover the anti-diarrheal, antioxidant, thrombolytic, and anthelmintic activities of methanol extract of $A$. solanacea (ASME) and its soluble $n$-hexane fraction in methanol (ASNH).

Materials and Methods: The phytochemical assessment of this plant was performed by using the standard method. The anti-diarrheal property was screened by castor oil induced diarrhea in Swiss albino mice and plant extract was administered into mice by oral gavage. The antioxidant property was being investigated by two different in vitro methods such as ferric reducing effect assay and superoxide scavenging activity assay. The thrombolytic activity was evaluated by in vitro clot lysis procedure, and the anthelmintic study was carried out on earthworm Pheretima posthuma.

Results: In castor-oil induced diarrhea, ASME and ASNH induced a significant decrease $\left({ }^{\star *} P<0.005\right)$ in the total number of defecation within 4 hours of the testing period $(200$ and $400 \mathrm{mg} / \mathrm{kg}$ ) when compared to the standard drug loperamide. During the evaluation of the antioxidant property, ASME showed promising reducing power with an $I_{50}$ value of 79.14 $\mu \mathrm{g} / \mathrm{mL}$ when compared to the standard ascorbic acid in ferric reducing effect assay. After that, ASME displayed significant scavenging effect with the $\mathrm{IC}_{50}$ value of $154.36 \mu \mathrm{g} / \mathrm{mL}$ when compared to standard curcumin in superoxide scavenging activity assay. In the thrombolytic activity, different doses of ASME and ASNH were used. These extracts produced considerable clot lysis of human blood, showed significant $(P<0.001)$ result in a concentration dependent manner. The crude ASME displayed anthelmintic activity in adult earth worm in a dose-dependent manner.
\end{abstract}

Conclusion: It can conclude that compared to standard drugs, A. solanacea have potential anti-diarrheal, antioxidant, thrombolytic, and anthelmintic activity.

Keywords: Ardisia solanacea, anti-diarrheal, antioxidant, thrombolytic, anthelmintic.

\section{INTRODUCTION}

Since ancient periods, a significant function was being played by different plant constituents or phytochemicals in the treatment and prevention of multiple human diseases [1]. Phytotherapy can be beneficial to treat life-threatening parasitic diseases [2]. Besides, herbal therapy can produce fewer side effects, cost-effective, and affordable [2]. The World Health Organization (WHO) concluded approximately about 20, 000 species of medicinal plants [3]. In most developing countries, the prime reason behind the mortality and morbidity is diarrhea that is most commonly caused by gastrointestinal infections. In every year, it is killing indiscriminately 4.6 million people, including 2.5 million children [4]. In 2015, Southern Asia and Sub-Saharan Africa were regions with the highest child death rates caused by diarrhea [5]. The use of lucid potable water is an important preventive measure against it. Eighty percent of people believe that medicinal plants can be used to treat diseases [6], including diarrhea. Traditional remedies

*Address correspondence to this author at the Department of Pharmacy, Faculty of Biological Sciences, University of Chittagong, Chittagong-4331, Bangladesh; Tel: +8801737660236; E-mail: mkhossain73@yahoo.com are the most considerable and in some cases the only source of therapeutics in treating diarrhea and most of the preparations come from plant origin [7]. Alternative therapies are using to treat diarrhea in recent times. Diarrhea has also been a prominent disease treated by traditional medicine [8]. In recent times, it is encouraged to isolate and investigate the phytochemicals in the modern sophisticated laboratory for finding the novel constituents [9].

In the food industry and medical research, antioxidants from spicy, aromatic, medical, and other plants were also searched to formulate natural antioxidant preparations for the food, cosmetics, and other uses [10]. Among them, phenolic components are very crucial for dietary uses and the most widely used in research [11]. Plants which are containing phenolic compounds constitute phenolic acids, flavonoids, and polyphenols such as hydrolyzable and condensed tannins [12]. These compounds can practically terminate oxidative stress by the process of scavenging free radicals which in turn gives protection to plant parts, fruits, and vegetables as well as protect human DNA, proteins, and lipids from oxidative embezzlement [12]. Free radical scavenging activities may contribute to the prevention of the inflammatory processes [13].

(C) 2020 SET Publisher 
This is because active $\mathrm{O}_{2}$ metabolites which are from phagocytic leukocytes that beset the tissues and cause injury to essential cellular components which lead to inflammatory tissue injuries [13]. Compounds that have scavenging properties towards these radicals are beneficial in inflammatory diseases [14, 15]. Herbal products have been applied to treat and prevent the incidence of cardiovascular diseases for a long time [16]. Many studies revealed that the natural compounds including medicinal herbs are most effective against atherosclerosis [17]. Plant extract decreased the level of serum lipid in rabbits fed with a high cholesterol diet [18]. Besides, recent studies have been revealed that the medicinal plants and their structural components possess antithrombotic activity [19]. The aerial parts of the plant also possess significant anthelmintic properties against different helminth parasites [20].

Our present investigation was done on a medicinal plant, named as Ardisia solanacea Roxb which belongs to Primulaceae family. In Bangladesh, it is locally called as Ban Jam and widely distributed in different regions of this country especially in hilly areas of Chittagong forest, Chittagong Hill Tracts, Sylhet and other evergreen forests. It is generally a small or glabrous tree that can reach a maximum height of 6 meters under the ordinary conditions [21]. This plant has potential antibacterial, neuropharmacological, oral hypoglycemic, cytotoxic, and antiviral properties were reported by the different research team [21, 22]. In this regard, the present study procedures mainly focused on to determine anti-diarrheal, antioxidant, antithrombotic, and anthelmintic properties of $A$. solanacea leaf extract.

\section{MATERIALS AND METHODS}

\subsection{Solvents and Chemicals}

The solvents and chemicals were used to maintain the analytical and laboratory-grade (e.g., SIGMA, E. Merck, or $\mathrm{BDH}$ ) solvents and chemicals were used in most of the experiments. Whitman No.1 (SargentWelch, USA), Tween-80, Loperamide (Square Pharmaceuticals Ltd., Bangladesh), Streptokinase (Skinase, Popular Pharmaceutical Ltd., Bangladesh), Pure methanol (Merck KGaA, Darmstadt, Germany), Potassium ferricyanide (1\%), Phosphate buffer saline, $0.1 \%$ ferric chloride, DMSO solution, and NBT (Nitroblue-tetrazolium).

\subsection{Plant Collection and Authentication}

The plant specimen of $A$. solanacea leaves were plucked from the hillside of Chittagong during the time of July, 2017. The collected specimen then identified by a senior Taxonomist, Dr. Shaikh Bokhtiar Uddin, Department of Botany, Faculty of Biological Sciences, University of Chittagong., included a herbarium number RI-12609004.

\subsection{Preparation of Plant Extract}

The specimen of proposed plant leaves were washed, whack, and then dried for several days before the grinding process. The grinding of dried specimens was executed by employing a high-speed grinder in the Phytochemistry Research lab, Department of Pharmacy, University of Chittagong. The grounded materials were then transferred into an airtight container for long term storage.

\subsection{Extraction of the Plant Material}

The ground plant specimen of $300 \mathrm{~g}$ was held in a sacred, round-bottom flask (5 liters) in which two liters of pure methanol was poured. The flask along with its content was sealed by aluminum foil and concealed a minimum of 15-20 days. After this soaking period, the mixed content was then filtered through a renewed cotton plug and the filtered content was again purified and filtered by Whitman No.1 filter's paper. The solvent volume present in the filtrate was then removed at very low temperature and pressure using the Buchii Rota Evaporator, Manufactured by Cole-Parmer, UK. After the solvent evaporation, a greenish-black colored semisolid methanol extract was attained with $25 \mathrm{~g}$ of yield index. This index was represented as \% yield, and calculation was done by using a simple mathematical approach [22].

\subsection{Preliminary Qualitative Phytochemicals Scree- ning}

The qualitative existence and exclusion of different secondary plant metabolites in this plant material were investigated by using standard procedures $[23,24]$.

\subsection{Experimental Animals}

For the evaluation of in vivo activity, young males, aged between 3-4 weeks of Swiss albino mice, having a mean weight of $20-25 \mathrm{~g}$. They were indiscriminately grasped from the Animal House of Pharmacy Department, Jahangirnagar University, Dhaka, Bangladesh. Then, they were sheltered in an especially engineered single clean plastic grate which was covered with a metal net on its top. These buckets of experimental animals were then shifted to the Animal House of the Department of Pharmacy, Faculty of 
Biological Sciences, University of Chittagong. The house was maintained at an optimum temperature of $24 \pm 1{ }^{\circ} \mathrm{C}$, RH (Relative humidity) kept at $55 \%-65 \%$, and 12 hours light-dark/ 12 hours dark circle. Then they were housed for one week and providing them with standard laboratory sustenance and water.

\subsection{Experimental Design}

To evaluate the antidiarrheal property induced by castor oil, thirty experimental animals were randomly elected, marked, weighed, and parted into six groups, each group consisting of five mice, and kept in a precleaned container.

Group (I): Normal control (Normal saline with $1 \%$ Tween-80; $0.1 \mathrm{~mL} / 10 \mathrm{~g}$ ).

Group (II): Positive control (Loperamide; $3 \mathrm{mg} / \mathrm{kg}$ ).

Group (III) and Group (IV): They were treated with 200 and $400 \mathrm{mg} / \mathrm{kg}$ of methanol extract of $A$. solanacea, respectively.

Group (V) and Group (VI): They were treated with 200 and $400 \mathrm{mg} / \mathrm{kg}$ of $\mathrm{n}$-hexane soluble fraction of methanol extract.

\subsection{Acute Toxicity Studies}

An acute toxicity study was directed to determine the $\mathrm{LD}_{50}$ for the extracts. According to the Organization for Economic Co-operation and Development (OECD) guidelines state that the use of a $2000 \mathrm{mg} / \mathrm{kg}$ rodent limit dose can cause acute oral toxicity. In compliance with this guideline 2008: 425 , a single female mouse was fasted for 3 hours and was charged with 2000 $\mathrm{mg} / \mathrm{kg}$ of ASME \& ASNH as a single dose by oral intubation. It was then examined for any sign of toxicity like as eyes, skin and fur, mucous membrane, circulatory and respiratory rate, and autonomic and CNS changes within the first 24 hours [25]. Based on the findings of the initially used mouse, the next four female mice were attained and fasted for 3 hours. Following that, they were treated with the same dose and again examined for any sign of toxicity or death in the next 14 days [26]. The effective therapeutic dose was calculated as one-tenth of the median lethal dose using the arithmetical model of Karber [27] in association with the Hodge and Sterner scale $\left(L_{50}>\right.$ $2.0 \mathrm{~g} / \mathrm{kg}$ ) [28]. The following equation was used for the calculation of $L D_{50}$ :

$$
L D 50=L D 100-\sum(a \times b) / n
$$

\subsection{Evaluation of Antidiarrheal Activity in Animal Model}

\subsubsection{Castor-Oil Induced Diarrhea}

To determine castor-oil induced diarrhea, we used a method which is described by Shoba and Thomas [29]. Here, a pure analytical grade castor oil of $1 \mathrm{~mL}$ was fed to rodents just after thirty minutes of oral administration of plant extracts. Then, they were kept under observation for the next four hours. The individual mouse had given defecation at each time been recorded.

\subsection{Evaluation of Antioxidant Activity}

\subsubsection{Ferric Reducing Effect Assay}

The reducing power of $A$. solanacea leaf extract was determined according to the modified method of Sanja [30]. In this method, the yellow-colored test solution changes to multiple shades of green and blue colours, indicating the reducing ability of the sample. Sample was prepared at the concentrations of $27.5,55$, 110,220 and $440 \mu \mathrm{g} / \mathrm{mL}$ in phosphate buffer saline $\left(\mathrm{p}^{\mathrm{H}}\right.$ = 6.6). $2.5 \mathrm{~mL}$ of potassium ferric cyanide $(1 \%)$ was mixed with standard and sample. This mixture of the reaction was incubated at $50^{\circ} \mathrm{C}$ for $20 \mathrm{~min}$. After a period of incubation, the reaction mixture was cooled and followed by the addition of $2.5 \mathrm{~mL}$ of trichloroacetic acid $(10 \%)$ by proper mixing. This mixture was centrifuged at $3000 \mathrm{rpm}$ for 10 minutes. The supernatant was collected and $2.5 \mathrm{~mL}$ of it was added to $2.5 \mathrm{~mL}$ of distilled water. Now, $1 \mathrm{~mL}$ of $0.1 \%$ ferric chloride was added to this reaction mixture and incubated at room temperature for $10 \mathrm{~min}$. Finally, the absorbance of this mixture was measured at $700 \mathrm{~nm}$. The standard ascorbic acid was used in this assay.

\subsubsection{Superoxide Scavenging Activity Assay by Alkaline DMSO Method}

Superoxide scavenging activity of $A$. solanacea extract was evaluated by the alkaline DMSO method described by Pandey with slight modification [31]. In this assay, the concentration of oxygen is abstracted in DMSO corresponds to the superoxide radical concentration in the alkaline DMSO solution. In brief, the non-enzymatic system of reaction generated this superoxide radical. The mixture of reaction was containing $0.3 \mathrm{~mL}$ of sample (Concentrations of 50 , $100,200,400$ and $800 \mu \mathrm{g} / \mathrm{mL}$ ) and $0.1 \mathrm{~mL}$ of NBT solution (1 $\mathrm{mg} / \mathrm{mL}$ solution in DMSO) in DMSO. Finally, $1 \mathrm{~mL}$ of alkaline DMSO $(1 \mathrm{~mL}$ DMSO containing $0.1 \mathrm{~mL}$ water with $5 \mathrm{mM} \mathrm{NaOH}$ ) was added to make a final volume of $1.4 \mathrm{~mL}$. Standard solution of different 
concentrations $(5,10,20,40,80 \mu \mathrm{g} / \mathrm{mL})$ was also prepared in this same way and curcumin was used as standard in this assay. The absorbance was assessed at $560 \mathrm{~nm}$. Plain DMSO of $300 \mathrm{~mL}$, alkaline DMSO of 1 $\mathrm{mL}$, and NBT (Nitro-blue-tetrazolium) solution of $0.1 \mathrm{~mL}$ was mixed to get control. Antioxidants with low absorbance at $560 \mathrm{~nm}$ indicate that the generated superoxide is consumed [32, 33]. The standard curcumin was employed in this test. In both methods, we only used crude methanol extract of $A$. solanacea to determine its antioxidant capacity.

\subsection{Evaluation of Thrombolytic Activity}

\subsubsection{In vitro Clot Lysis Model}

\subsubsection{Blood Specimen}

Whole venous blood $(5 \mathrm{~mL})$ was drawn from healthy volunteers $(n=10)$ without a history of oral contraception or anticoagulant therapy. An informed consent form was filled up by every subject participating willingly in this research project [34]. A lab technician from the Department of Pharmacy, University of Chittagong, who collected the blood from the volunteers, preserved the blood by the same lab personnel. The clot-bearing Eppendorf tubes were stored in the refrigerator of the Microbiology laboratory of the same Department.

\subsubsection{Study Design}

This experiment was conducted by the method described earlier by Prasad et al. [35]. In short, $5 \mathrm{~mL}$ of venous blood drawn from the participated healthy volunteers which, was distributed in different preweighted sterile eppendorf tubes ( $500 \mu \mathrm{L}$ per tube) and the tubes were then incubated in an incubator at $37^{\circ} \mathrm{C}$ for 45 minutes to occur blood-clot. After clot formation, without disrupting the clot, the separated serum was completely removed, and then each tube containing the clot was again weighed to ascertain the clot weight (Clot weight= weight of clot-containing tube - weight of the tube alone). To each clot-containing eppendorf tube, different doses $(5,10$, and $20 \mathrm{mg} / \mathrm{mL})$ of methanol extract and its soluble n-hexane of $A$. solanacea leave was added separately. The amount of plant extract was $500 \mu \mathrm{l}$ of each dose. Streptokinase $(100 \mu \mathrm{L})$, positive control, and a negative nonthrombolytic control (100 $\mu \mathrm{L}$ of distilled water) were individually added to the numbered control tubes. After then, all the tubes containing extract, positive, and negative control were incubated at $37^{\circ} \mathrm{C}$ for the next 90 minutes and executed for clot lysis. After this incubation period, the released fluid was removed and the tubes were again weighed to observe dissimilation of the weight of the clot after breakdown. The observed dissimilation in the weight taken before and after clot lysis was expressed as the percentage of clot lysis.

\subsection{In vitro Evaluation of Anthelmintic Activity}

The anthelmintic property of plant extract was done by following the method of Ajaiyeoba [36]. This was done on adult earthworms Pheretima posthuma. These were collected from the waterlogged areas, near the campus of the University of Chittagong. Appraised by veterinary technicians, the collected earth is $3-5 \mathrm{~cm}$ long, 0.1-0.2 cm wide, and weighs $0.8-3.04 \mathrm{~g}$. They were thoroughly washed with saline water. The different concentrations $(10-50 \mathrm{mg} / \mathrm{mL})$ of investigated plant extract were prepared. The final volume of each concentration was made to $10 \mathrm{~mL}$, and then transferred to different Petri dishes. The marketed albendazole was used as a standard drug. These earthworms were delivered into Petri dishes each containing five earthworms. Continuous observations were made to look-out any physical changes (paralysis and death) in the earthworms.

\subsection{Statistical Analysis}

Data were represented as mean \pm standard error (SE). All statistical analysis of both control and treated samples of $A$. solanacea leaf extract were performed by one-way analysis of variance (ANOVA) Dunnett's $t$ test where ${ }^{*} P<0.05$ was regarded as statistically significant. In addition, all data were analyzed by using SPSS tools (Version: 20, IBM Corporation, New York, USA). IC50 values were estimated by using linear regression equations through the usage of Microsoft Excel 2007 (Microsoft, Redmond, Washington, USA).

\section{RESULT}

\subsection{Preliminary Qualitative Phytochemicals Screening}

This study was conducted to screen for the presence of different phytochemicals in the plant. The investigation carried out revealed that Table 1 showed the presence of alkaloids, tannins, steroids, flavonoids, carbohydrates, glycosides, especially anthracene glycosides, phenols, proteins, terpenoids (triterpenoids).

\subsection{Oral Acute Toxicity}

The oral acute toxicity dose experiment was done by using of the limit dose of $2000 \mathrm{mg} / \mathrm{kg} \mathrm{B} / \mathrm{W}$ of the 
Table 1: Presence of Phytochemicals in Ardisia solanacea Leaf Extract

\begin{tabular}{|c|c|c|c|}
\hline Phytochemicals & Test & ASME & ASNH \\
\hline \multirow{2}{*}{ Steroids } & Salkowski's test & + & - \\
\hline & Liebermann-Burchard test & + & - \\
\hline Tannins & $\mathrm{FeCl}_{3}$ test & ++ & - \\
\hline \multirow{2}{*}{ Flavonoids } & $\mathrm{Zn}-\mathrm{HCl}$ reduction test & ++ & + \\
\hline & Lead acetate test & + & - \\
\hline \multirow{2}{*}{ Triterpenes } & Salkowski's test & + & - \\
\hline & Liebermann-Burchard test & + & - \\
\hline \multirow{2}{*}{ Saponins } & Shake or foam test or froth test. & ++ & ++ \\
\hline & Olive oil test & + & ++ \\
\hline Protein & Molisch's test & + & + \\
\hline Phenols & Test with $1 \%$ of copper sulphate solution and $\mathrm{NaOH}$ & + & + \\
\hline Carbohydrate & Fehling's test & ++ & + \\
\hline Anthraquinones glycosides & Hydroxy anthraquinones & - & - \\
\hline Resins & Test with acetone solution & ++ & + \\
\hline Fats or fixed oils & Biuret test & ++ & + \\
\hline Glycosides & $\mathrm{NaOH}$ test & ++ & + \\
\hline Cardiac-glycosides & Keller- killiani test & + & - \\
\hline \multirow{4}{*}{ Alkaloids } & Dragendorff's test & ++ & + \\
\hline & Mayer's test & + & ++ \\
\hline & Hager's test & + & + \\
\hline & Wagner's test & + & + \\
\hline
\end{tabular}

Note: $\mathrm{ASME}=$ methanol extract of $A$. solanacea, $\mathrm{ASNH}=$ soluble $\mathrm{n}$-hexane fraction in methanol extract, Bioavailability Indicator: $(++)$ ve $=$ High presence, $(+)$ ve $=$ Medium presence, $(-)$ ve= Absence.

mouse commenced safely since at this dose the experimental animals didn't show any apparent physical and behavioral changes, ascertaining that the $L_{50}$ of the extract is greater than $2000 \mathrm{mg} / \mathrm{kg}$.

\subsection{Evaluation of Antidiarrheal Activity}

At both doses of 200 and $400 \mathrm{mg} / \mathrm{kg}$, the methanol extract along with soluble n-hexane fraction induced a gradual decrease in the total number of defecation in 4 hours of the experiment while compared to the control. In these doses, ASME induced $49.27 \%$ \& $63.77 \%$ of inhibition which was significant $\left({ }^{* *} P<0.005\right)$ whereas, ASNH resulted $40.58 \%$ \& $56.52 \%$ of inhibition $\left({ }^{* *} P<0.005\right)$ respectively. This is almost equivalent to the standard drug loperamide $(65.22 \%$ inhibition, $\left.{ }^{* *} P<0.005\right)$, as shown in Tables $2 \& 3$.

\subsection{Evaluation of Antioxidant Activity}

\subsubsection{Ferric Reducing Effect Assay}

The methanol extract at a concentration of 440 $\mu \mathrm{g} / \mathrm{mL}$, produced the highest reducing power of $73.53 \pm$
$3.44 \%$. Yet, the standard ascorbic acid at a concentration of $250 \mu \mathrm{g} / \mathrm{mL}$ showed the highest reducing power of $89.35 \pm 3.39 \%$. Moreover, the methanol extract produced an $\mathrm{IC}_{50}$ value of 79.14 $\mu \mathrm{g} / \mathrm{mL}$ whereas, ascorbic acid showed $71.03 \mu \mathrm{g} / \mathrm{mL}$. All these results are shown in Table 4.

\subsubsection{Superoxide Scavenging Activity Assay}

The results showed in Table $\mathbf{5}$, revealed that the methanol extract induced scavenging property at multiple concentrations $(5,10,20,40$, and $80 \mu \mathrm{g} / \mathrm{mL})$. Here, the highest scavenging, i.e., $82.66 \pm 0.30 \%$ was observed at $800 \mu \mathrm{g} / \mathrm{mL}$. On the other hand, it was $96.43 \pm 0.16 \%$ at $80 \mu \mathrm{g} / \mathrm{mL}$ in the case of standard curcumin. Yet, the methanol extract displayed $I C_{50}$ value of $154.36 \mu \mathrm{g} / \mathrm{mL}$, whereas, the curcumin showed $0.0000125 \mu \mathrm{g} / \mathrm{mL}$.

\subsection{Evaluation of Thrombolytic Activity}

In Table 6, the methanol extract induced $26.02 \%$ $\left({ }^{* *} P<0.001\right)$ of thrombolytic action whereas, soluble 
Table 2: Evaluation of Antidiarrheal Activity of Crude Extract and its n-Hexane Fraction of Ardisia solanacea

\begin{tabular}{|c|c|c|c|c|c|c|c|}
\hline \multirow{2}{*}{ Group } & \multirow{2}{*}{$\begin{array}{l}\text { Number of } \\
\text { mice }\end{array}$} & \multicolumn{4}{|c|}{ Number of defecation by each mouse in different hours } & \multirow{2}{*}{$\begin{array}{l}\text { Total number } \\
\text { of defecation }\end{array}$} & \multirow{2}{*}{$\begin{array}{c}\text { Average number } \\
\text { of defecation }\end{array}$} \\
\hline & & $1^{\text {st }}$ & $2^{\text {nd }}$ & $3^{\text {rd }}$ & $4^{\text {th }}$ & & \\
\hline \multirow{5}{*}{ Control } & $\mathrm{M}-1$ & 2 & 4 & 3 & 3 & 12 & \multirow{5}{*}{13.80} \\
\hline & M-2 & 4 & 3 & 5 & 3 & 15 & \\
\hline & M-3 & 2 & 4 & 5 & 0 & 11 & \\
\hline & $M-4$ & 3 & 3 & 3 & 5 & 14 & \\
\hline & $M-5$ & 3 & 6 & 4 & 4 & 17 & \\
\hline \multirow{5}{*}{$\begin{array}{c}\text { Standard } \\
\text { (Loperamide) }\end{array}$} & $\mathrm{M}-1$ & 1 & 1 & 1 & 1 & 04 & \multirow{5}{*}{4.80} \\
\hline & $\mathrm{M}-2$ & 0 & 1 & 1 & 3 & 05 & \\
\hline & $M-3$ & 0 & 2 & 2 & 2 & 06 & \\
\hline & $\mathrm{M}-4$ & 1 & 1 & 2 & 0 & 04 & \\
\hline & $M-5$ & 0 & 1 & 2 & 2 & 05 & \\
\hline \multirow{5}{*}{ ASME 200} & $\mathrm{M}-1$ & 0 & 1 & 3 & 3 & 7 & \multirow{5}{*}{7.00} \\
\hline & M-2 & 1 & 2 & 2 & 2 & 7 & \\
\hline & $M-3$ & 1 & 1 & 2 & 2 & 6 & \\
\hline & $\mathrm{M}-4$ & 1 & 2 & 1 & 2 & 6 & \\
\hline & $M-5$ & 1 & 2 & 3 & 3 & 9 & \\
\hline \multirow{5}{*}{ ASME 400} & $\mathrm{M}-1$ & 1 & 2 & 1 & 2 & 6 & \multirow{5}{*}{5.20} \\
\hline & M-2 & 0 & 1 & 2 & 1 & 4 & \\
\hline & $M-3$ & 1 & 2 & 1 & 2 & 6 & \\
\hline & $\mathrm{M}-4$ & 0 & 1 & 2 & 2 & 5 & \\
\hline & M-5 & 0 & 1 & 3 & 1 & 5 & \\
\hline \multirow{5}{*}{ ASNH 200} & $\mathrm{M}-1$ & 1 & 3 & 2 & 3 & 9 & \multirow{5}{*}{8.20} \\
\hline & $M-2$ & 1 & 1 & 3 & 2 & 7 & \\
\hline & M-3 & 1 & 2 & 2 & 2 & 7 & \\
\hline & M-4 & 1 & 2 & 2 & 4 & 9 & \\
\hline & $M-5$ & 1 & 1 & 4 & 3 & 9 & \\
\hline \multirow{5}{*}{ ASNH 400} & $M-1$ & 0 & 2 & 1 & 2 & 5 & \multirow{5}{*}{6.40} \\
\hline & M-2 & 1 & 3 & 2 & 2 & 8 & \\
\hline & $\mathrm{M}-3$ & 1 & 1 & 1 & 2 & 5 & \\
\hline & $M-4$ & 1 & 1 & 2 & 3 & 7 & \\
\hline & M-5 & 1 & 1 & 3 & 2 & 7 & \\
\hline
\end{tabular}

Here, $\mathrm{M}=$ Mice, $\mathrm{ASME}=$ methanol extract of Ardisia solanacea, $\mathrm{ASNH}=\mathrm{n}$ - hexane soluble fraction.

Table 3: Evaluation of Antidiarrheal Activity of Methanol Extract and its n-Hexane Fraction of Ardisia solanacea

\begin{tabular}{|c|c|c|c|c|c|c|}
\hline \multirow[b]{2}{*}{ Animal group } & \multirow{2}{*}{$\begin{array}{l}\text { Dose } \\
\text { (Mg/kg) }\end{array}$} & \multicolumn{5}{|c|}{ Mean士SEM } \\
\hline & & $\begin{array}{l}1^{\text {st }} \mathrm{hr}(\% \text { of } \\
\text { inhibition) }\end{array}$ & $\begin{array}{c}2^{\text {nd }} \mathrm{hr} \text { (\% of } \\
\text { inhibition) }\end{array}$ & $\begin{array}{l}3^{\text {rd }} \mathrm{hr}(\% \text { of } \\
\text { inhibition) }\end{array}$ & $\begin{array}{l}4^{\text {th }} \mathrm{hr}(\% \text { of } \\
\text { inhibition) }\end{array}$ & $\begin{array}{l}\text { Total (\% of } \\
\text { inhibition) }\end{array}$ \\
\hline Standard & 10 & $\begin{array}{c}0.40 \pm 0.24 \\
85.57 \%\end{array}$ & $\begin{array}{c}1.20 \pm 0.20 * \\
70.00 \%\end{array}$ & $\begin{array}{c}1.60 \pm 0.24 * \\
60.00 \%\end{array}$ & $\begin{array}{c}1.60 \pm 0.50 \\
46.67 \%\end{array}$ & $\begin{array}{c}4.80 \pm 0.37^{* *} \\
65.22 \%\end{array}$ \\
\hline ASME 200 & 200 & $\begin{array}{c}0.80 \pm 0.20 * \\
71.43 \%\end{array}$ & $\begin{array}{c}1.60 \pm 0.24 \\
60.00 \%\end{array}$ & $\begin{array}{c}2.20 \pm 0.34 \\
45.00 \%\end{array}$ & $\begin{array}{c}2.40 \pm 0.25 \\
20.00 \%\end{array}$ & $\begin{array}{c}7.00 \pm 0.55^{* *} \\
49.27 \%\end{array}$ \\
\hline ASME 400 & 400 & $\begin{array}{c}0.40 \pm 0.24 \\
85.57 \%\end{array}$ & $\begin{array}{c}1.40 \pm 0.25^{* *} \\
65.00 \%\end{array}$ & $\begin{array}{c}1.80 \pm 0.34^{*} \\
55.00 \%\end{array}$ & $\begin{array}{c}1.60 \pm 0.24 \\
46.67 \%\end{array}$ & $\begin{array}{c}5.00 \pm 0.37^{* *} \\
63.77 \%\end{array}$ \\
\hline ASNH 200 & 200 & $\begin{array}{c}1.00 \pm 0.00 * * \\
64.28\end{array}$ & $\begin{array}{c}1.80 \pm 0.37^{* *} \\
55 \%\end{array}$ & $\begin{array}{c}2.60 \pm 0.40 \\
35.00 \%\end{array}$ & $\begin{array}{c}2.80 \pm 0.34 \\
6.67 \&\end{array}$ & $\begin{array}{c}8.20 \pm 0.49^{* *} \\
40.58 \%\end{array}$ \\
\hline ASNH 400 & 400 & $\begin{array}{c}0.80 \pm 0.20 \\
71.43 \%\end{array}$ & $\begin{array}{c}1.60 \pm 0.40 * \\
60.00 \%\end{array}$ & $\begin{array}{c}1.80 \pm 0.37^{*} \\
55.00 \%\end{array}$ & $\begin{array}{c}2.20 \pm 0.20 \\
26.67 \%\end{array}$ & $\begin{array}{c}6.00 \pm 0.60^{* *} \\
56.52 \%\end{array}$ \\
\hline
\end{tabular}

Note: Each value represents the mean \pm SEM. $(n=5)$. One- way ANOVA followed by Dunnett's $t$ test. ${ }^{* \prime} P<0.005,{ }^{~} P<0.01,{ }^{*} P<0.05$ compared with control. ASME= methanol extract of Ardisia solanacea, $\mathrm{ASNH}=\mathrm{n}$ - hexane soluble fraction. 
Table 4: $\quad \mathrm{FeCl}_{3}$ Reducing Effect (\%) of Methanol Extract of Ardisia solanacea

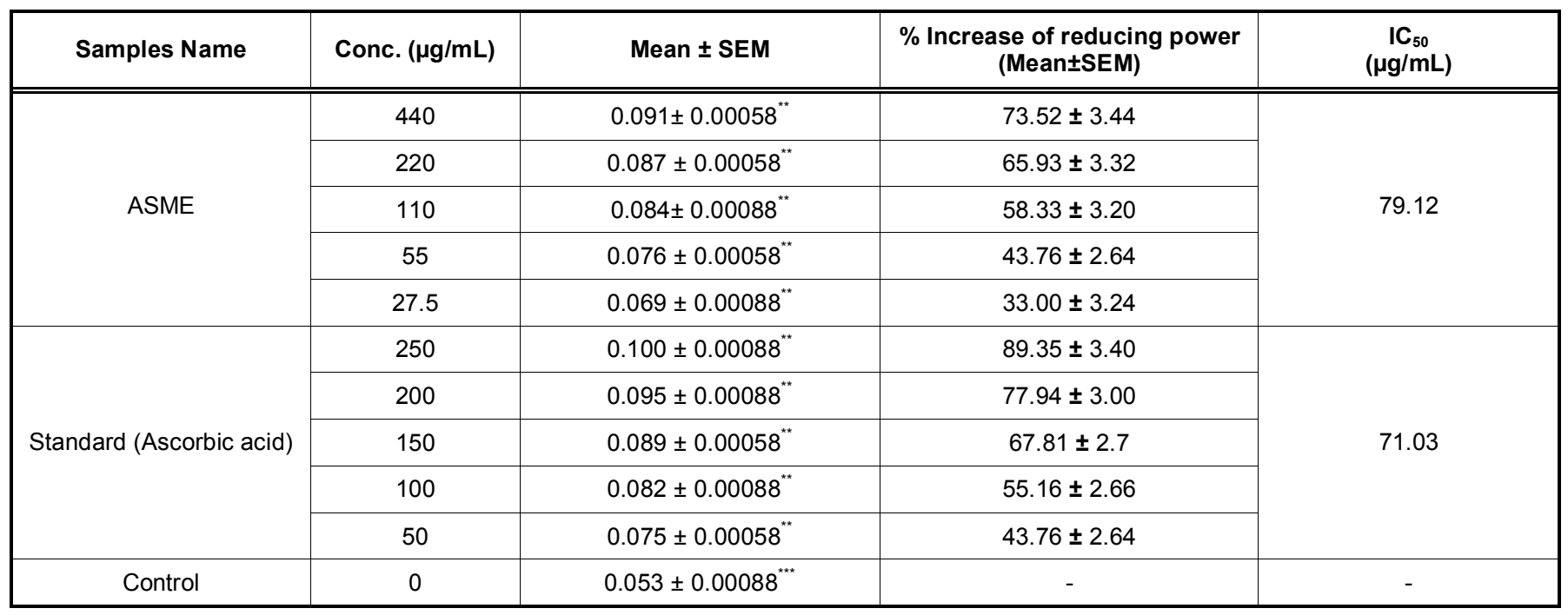

Data are shown as Mean \pm SD for triplicate. Data were analyzed by one-way ANOVA followed by Tukey's post hoc test (SPSS, Version 20.0, and NY) for multiple comparisons. Values with ${ }^{* *} P<0.005$ were considered as significant. ASME= methanol extract of Ardisia solanacea.

Table 5: Superoxide Scavenging (\%) Activity of Methanol Extract of Ardisia solanacea

\begin{tabular}{|c|c|c|c|c|}
\hline Samples Name & Conc. $(\mu \mathrm{g} / \mathrm{mL})$ & Mean士SEM & $\begin{array}{l}\% \text { Increase of superoxide scavenging } \\
\text { (Mean } \pm \text { SEM) }\end{array}$ & $\begin{array}{c}\mathrm{IC}_{50} \\
(\mu \mathrm{g} / \mathrm{mL})\end{array}$ \\
\hline \multirow{3}{*}{ ASME } & 800 & $0.50 \pm 0.004^{* *}$ & $82.6 \pm 0.30$ & \multirow{3}{*}{154.36} \\
\hline & 200 & $0.19 \pm 0.001^{* *}$ & $54.01 \pm 0.54$ & \\
\hline & 100 & $0.15 \pm 0.001^{* *}$ & $40.96 \pm 0.78$ & \\
\hline \multirow{4}{*}{ Standard (Curcumin) } & 80 & $2.51 \pm 0.002^{* *}$ & $96.42 \pm 0.16$ & \multirow{4}{*}{0.00001} \\
\hline & 40 & $1.80 \pm 0.002^{* *}$ & $95.23 \pm 0.06$ & \\
\hline & 20 & $1.57 \pm 0.001^{* *}$ & $94.52 \pm 0.075$ & \\
\hline & 10 & $1.32 \pm 0.003^{* *}$ & $93.51 \pm 0.08$ & \\
\hline
\end{tabular}

Data are shown as Mean \pm SD for triplicate. Data were analyzed by one-way ANOVA followed by Tukey's post hoc test (SPSS, Version 20.0, and NY) for multiple comparisons. Values with " $P<0.005$ were considered most significant. ASME= methanol extract of Ardisia solanacea.

n-hexane fraction induced $24.03 \%\left({ }^{* * *} P<0.001\right)$ of human blood to dissolve at a dose of $10 \mathrm{mg} / \mathrm{mL}$ as compared to the control. Besides, standard drug streptokinase $(30,000$ I.U.) displayed $48.66 \%$ of clot lysis. Except for the highest dose $(20 \mathrm{mg} / \mathrm{mL})$, ASME and ASNH both showed more significant results, respectively $32.64 \%$ and $33.42 \%$, as shown in Tables 6 and 7.

\subsection{Evaluation of Anthelmintic Activity}

The significant activity of the methanol extract was observed at the highest dose $(50 \mathrm{mg} / \mathrm{mL})$ on adult earthworm while the standard drug albendazole showed significant activity at a dose of $10 \mathrm{mg} / \mathrm{mL}$.

\section{DISCUSSION}

In this ethnopharmacological study, A. solanacea leaf extract was experimented for preliminary phytochemicals screening, anti-diarrheal, antioxidant, thrombolytic, and anthelmintic property. However, the leaves of this plant are usually applied for the dealing of various health problems [22].

In symphony with OECD guidelines, the $\mathrm{LD}_{50}$ was found to be $>2000 \mathrm{mg} / \mathrm{kg}$ for the experimental extracts. Henceforth, the LD50 of experimental extracts found three times the minimum effective dose $(100 \mathrm{mg} / \mathrm{kg})$, it was taken as an appropriate candidate for the studies [37]. 
Table 6: Effect of Methanol Extract and its n- Hexane Soluble Fraction of Ardisia solanacea in Clot Lysis of Human Blood In-vitro

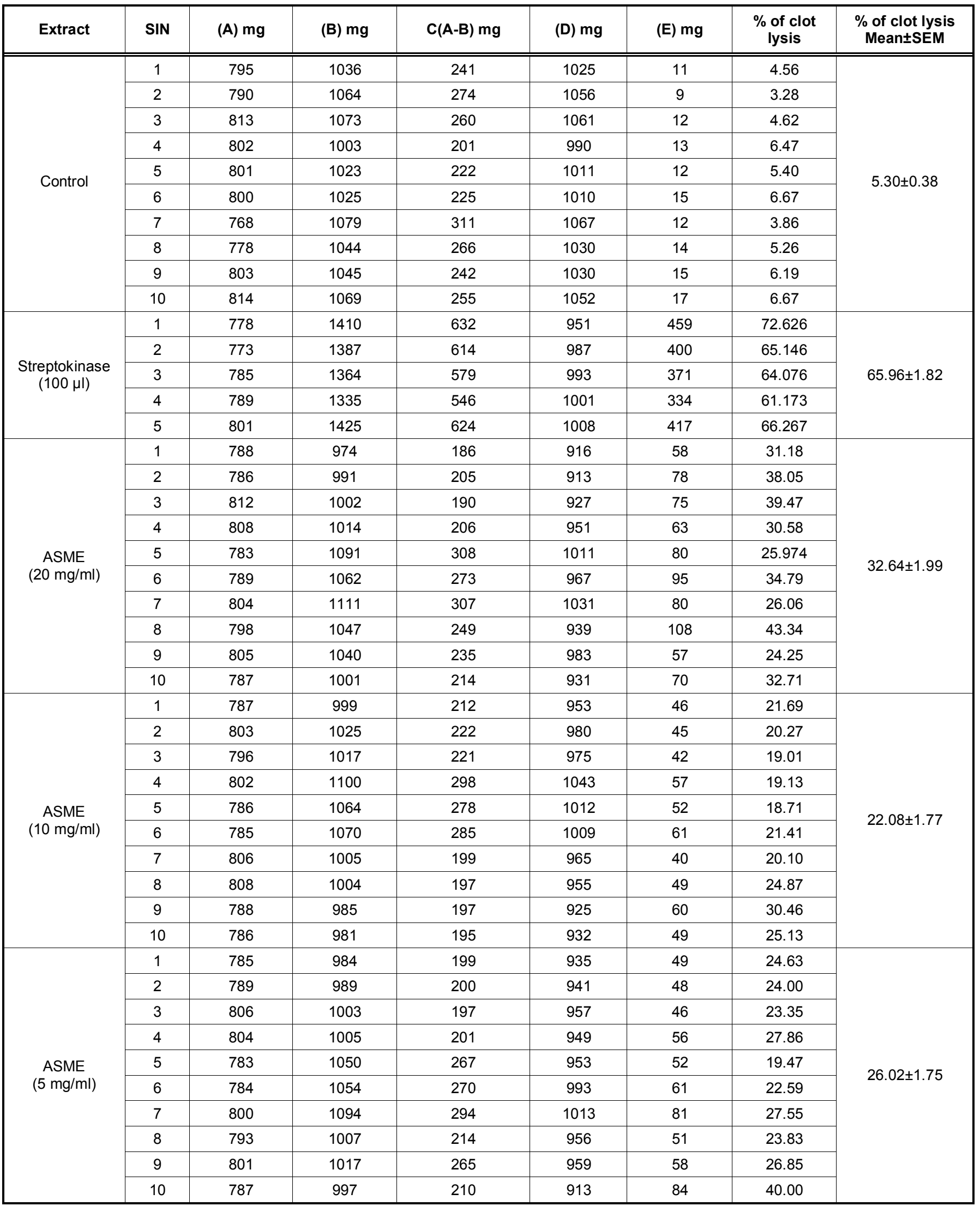


(Table 6). Continued.

\begin{tabular}{|c|c|c|c|c|c|c|c|c|}
\hline Extract & SIN & (A) $\mathrm{mg}$ & (B) $\mathrm{mg}$ & $C(A-B) m g$ & (D) $\mathrm{mg}$ & (E) $\mathrm{mg}$ & $\begin{array}{l}\% \text { of clot } \\
\text { lysis }\end{array}$ & $\begin{array}{c}\% \text { of clot lysis } \\
\text { Mean } \pm S E M\end{array}$ \\
\hline \multirow{10}{*}{$\begin{array}{c}\text { ASNH } \\
(20 \mathrm{mg} / \mathrm{ml})\end{array}$} & 1 & 771 & 992 & 221 & 933 & 59 & 26.69 & \multirow{10}{*}{$33.42 \pm 2.78$} \\
\hline & 2 & 823 & 1050 & 227 & 977 & 73 & 32.16 & \\
\hline & 3 & 803 & 1013 & 210 & 897 & 116 & 55.24 & \\
\hline & 4 & 806 & 1022 & 216 & 953 & 69 & 31.95 & \\
\hline & 5 & 788 & 978 & 190 & 926 & 52 & 27.37 & \\
\hline & 6 & 779 & 1026 & 247 & 925 & 101 & 40.89 & \\
\hline & 7 & 785 & 1117 & 332 & 1017 & 100 & 30.12 & \\
\hline & 8 & 800 & 1157 & 357 & 1050 & 107 & 29.97 & \\
\hline & 9 & 786 & 1041 & 255 & 995 & 66 & 25.88 & \\
\hline & 10 & 809 & 1057 & 248 & 973 & 84 & 33.87 & \\
\hline \multirow{10}{*}{$\begin{array}{c}\text { ASNH } \\
(10 \mathrm{mg} / \mathrm{ml})\end{array}$} & 1 & 805 & 1049 & 244 & 997 & 52 & 21.32 & \multirow{10}{*}{$24.03 \pm 2.16$} \\
\hline & 2 & 787 & 1022 & 235 & 983 & 39 & 16.59 & \\
\hline & 3 & 799 & 1057 & 258 & 1013 & 44 & 17.05 & \\
\hline & 4 & 784 & 1017 & 233 & 977 & 40 & 17.17 & \\
\hline & 5 & 780 & 1023 & 243 & 967 & 56 & 23.05 & \\
\hline & 6 & 789 & 988 & 199 & 936 & 52 & 26.13 & \\
\hline & 7 & 803 & 1013 & 210 & 965 & 48 & 22.86 & \\
\hline & 8 & 806 & 998 & 192 & 928 & 70 & 36.46 & \\
\hline & 9 & 821 & 1019 & 198 & 968 & 51 & 25.76 & \\
\hline & 10 & 775 & 999 & 224 & 923 & 76 & 33.93 & \\
\hline \multirow{10}{*}{$\begin{array}{c}\text { ASNH } \\
(5 \mathrm{mg} / \mathrm{ml})\end{array}$} & 1 & 773 & 998 & 225 & 949 & 49 & 21.78 & \multirow{10}{*}{$19.57 \pm 0.98$} \\
\hline & 2 & 819 & 1009 & 190 & 973 & 36 & 18.37 & \\
\hline & 3 & 803 & 999 & 196 & 951 & 48 & 24.49 & \\
\hline & 4 & 800 & 1003 & 203 & 967 & 36 & 17.73 & \\
\hline & 5 & 788 & 997 & 209 & 948 & 49 & 23.45 & \\
\hline & 6 & 779 & 1013 & 234 & 968 & 45 & 19.23 & \\
\hline & 7 & 781 & 1007 & 226 & 959 & 48 & 21.24 & \\
\hline & 8 & 800 & 1047 & 247 & 1011 & 36 & 14.57 & \\
\hline & 9 & 784 & 1012 & 228 & 972 & 40 & 17.54 & \\
\hline & 10 & 801 & 1038 & 237 & 997 & 41 & 17.30 & \\
\hline
\end{tabular}

$\mathrm{SIN}=$ Sample Identification number, $\mathrm{A}=$ Initial weight of eppendorf tube, $\mathrm{B}=$ weight of tube after clot formation, $\mathrm{C}=\mathrm{Weight}$ of clot, $\mathrm{D}=\mathrm{Weight}$ the tube after application of sample, $\mathrm{E}=$ Weight of lysis, $\mathrm{ASME}=$ methanol extract of $A$. solanacea, $\mathrm{ASNH}=\mathrm{n}$-hexane soluble fraction.

Table 7: Effect of Methanol Extract and its $\mathrm{n}$ - Hexane Soluble Fraction of Ardisia solanacea in Clot Lysis of Human Blood In-vitro

\begin{tabular}{|c|c|}
\hline Samples & $\%$ of Clot Lysis (Mean \pm SEM) \\
\hline Control & $5.30 \pm 0.38$ \\
\hline Streptokinase (100 uL) & $65.96 \pm 1.82^{* \star *}$ \\
\hline ASME $(20 \mathrm{mg} / \mathrm{mL})$ & $32.64 \pm 1.99^{\star * *}$ \\
\hline ASME (10 mg/mL) & $22.08 \pm 1.77^{\star * *}$ \\
\hline ASME(5 mg/mL) & $19.57 \pm 0.98^{\star * *}$ \\
\hline $\mathrm{ASNH}(20 \mathrm{mg} / \mathrm{mL})$ & $33.42 \pm 2.78^{\star \star \star}$ \\
\hline $\mathrm{ASNH}(10 \mathrm{mg} / \mathrm{mL})$ & $24.03 \pm 2.16^{\star * *}$ \\
\hline ASNH(5 mg/mL) & $19.57 \pm 0.98^{\star * *}$ \\
\hline
\end{tabular}

Each value represents the mean \pm SEM, $(n=10)$. One- way ANOVA followed by Dunnett's $t$ test. ${ }^{* *} P<0.001,{ }^{* *} P<0.01$ compared with control. ASME $=$ methanol extract of $A$. solanacea, $\mathrm{ASNH}=\mathrm{n}$ - hexane soluble fraction. 


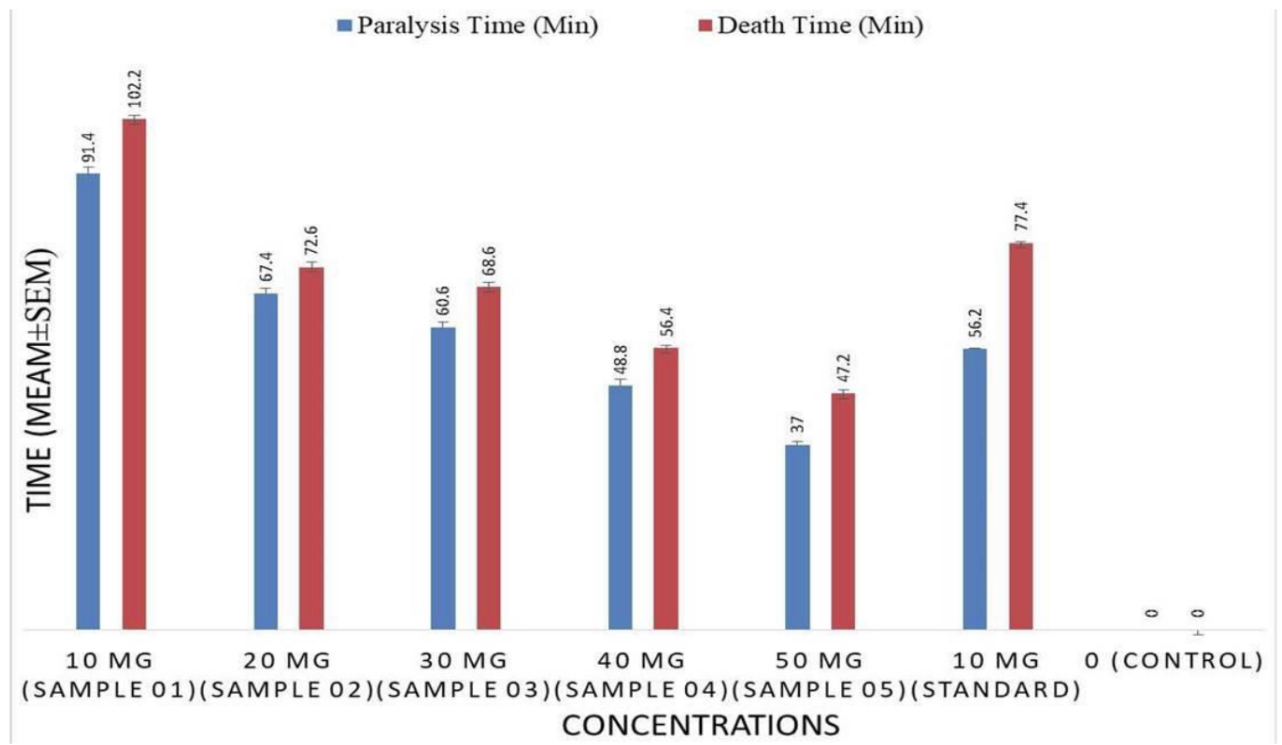

Figure 1: Time for paralysis and death of earthworms for extract and standard, ASME= Methanol extract of Ardisia solanacea leaves.

An alteration happens in active ion transport by decreased sodium absorption, and increased chloride ion secretion which can enhance luminal osmolarity, variation in intestinal rapidity, or in increased tissue hydrostatic pressure is an index of diarrhea [38]. These mechanisms revealed that the lipases act on castor-oil in which ricinoleic acid is liberated, and this ricinoleic acid initiates inflammatory, and irritating actions on the intestinal mucosa commencing to the release of prostaglandins [39]. The antidiarrheal agent acts on these pathophysiologic processes and causes them to inhibit. To evaluate the antidiarrheal property, a castoroil induced method was applied in this study which is well documented [40, 41]. In this experiment, defecation frequency, and fluid content present in stool was inhibited and reduced, respectively by ASME, and ASNH at both doses of 200 and $400 \mathrm{mg} / \mathrm{kg}$, in a dosedependent way. The antidiarrheal activity of $A$. solanacea leaf in a dose-dependent process equips it more parallel to other plant extracts [42]. Nevertheless, there are numerous phytochemicals (such as tannins, flavonoids, alkaloids, and terpenes) present in plant extracts. The anti-diarrheal property of plant extract has been revealed if they possess flavonoids and tannins in their chemical profile [43]. The preliminary phytochemical screening of $A$. solanacea revealed the existence of these substances.

The plant extract containing phenolic compounds can significantly promote plant defense mechanisms. In pathophysiological processes both in animals and humans, they play a vital role. To identify the scavenging effect of this plant extract, ferric oxide effect assay was used in this study. The reducing power of a compound may tend to indicate potential and significant antioxidant activity [44]. The methanol extract along with the standard drug ascorbic acid showed their reducing capacity at concentrations between 50 and $250 \mu \mathrm{g} / \mathrm{mL}$. They produced high absorbance at these ranges and exhibited high reducing activity [45]. As it is happened, because this plant extract may contain antioxidant molecules that render the conversion of ferricyanide $\left(\mathrm{Fe}^{3+}\right)$ complex to the ferrous form [46]. Again, the methanol extract was representing promising $\left({ }^{* *} P<0.005\right) I C_{50}$ value as the cut-off value of $\mathrm{IC}_{50}$ corresponds to $1000 \mu \mathrm{g} / \mathrm{mL}$ and this indicates the extract can initiate radical-scavenging reactions [47]. Again the same property was being examined by another method named superoxide scavenging assay technique. Plant extract that was treated with $\mathrm{NaOH}$-alkaline DMSO-NBT system, an artificially created system results in the formation of the blue formazan [48]. The inhibitory effect of the extract on the formation of formazan is reflected by the $I_{50}$ value.

Here, the $\mathrm{IC}_{50}$ value of plant extract remained below the standard substance curcumin. The results showed that the plant extract produced a significant superoxide scavenging effect $\left({ }^{* *} P<0.005\right)$ as compared to standard curcumin. It means that the leaves of $A$. solanacea are capable of inhibiting non-enzymatic superoxide radical, which is simultaneously generated in the biological system. Superoxide-radical is a precursor of many ROS and is speculated to be harmful to various cellular components, however, both anaerobic and aerobic 
organisms contain an enzyme superoxide dismutase that can catalyze the superoxide radical [49]. Again phytochemical analysis of our plant extract identified the existence of several phytochemicals (saponins, tannins, flavonoids, and terpenoids) that they may scavenge free radicals [50] as well as inhibit lipidperoxidation [51, 52].

Now, the antithrombotic effect of this plant was evaluated by the in vitro clot lysis method and no clot lysis observed inside the eppendorf when distilled water was added to it. As usual, the standard drug streptokinase produced significant $\left({ }^{* *} P<0.001\right)$ thrombolytic clot lysis. In comparison to standard, ASME and ASNH showed that the antithrombotic effect was lower. As compared to control (Distilled water), they produced the effect was significant $\left({ }^{* *} P<0.001\right)$. Literally streptokinase is proved to be a bacterial plasminogen activator liquefy clots and plays a role to annihilate fibrin and the extracellular matrix that endure cells together $[53,54]$. The phytochemical glycoside was found in the plant extract may play thrombolytic action in it [55].

Finally, the anthelmintic effect action of this plant extract was investigated on an earthworm. The methanol extract displayed its anthelmintic action by creating paralysis and consequently producing the death of earthworm in a dose-dependent manner. The plant contains alkaloid, phenols, tannins which are secondary metabolite can cause paralysis on earthworm by producing the effect on central nervous system [56].

\section{CONCLUSION}

This study implicates antidiarrheal, antioxidant, thrombolytic, and anthelmintic properties of $A$. solanacea leaves extract. Among them, antioxidant and antidiarrheal properties were significantly distinguished. Further research interventions are required to expand on the leaves of this plant to find out which compounds are exactly responsible for these pharmacological activities.

\section{ACKNOWLEDGEMENTS}

Authors are thankful to the Department of Pharmacy, University of Chittagong for the earnest cooperation by providing laboratory support to carry out the whole study. The authors would like to thank Professor Dr. Shaikh Bokhtear Uddin, Department of Botany, University of Chittagong for the identification of the plant. The authors are also thankful to Md. Saddam Hussain for his help.

\section{AUTHOR'S CONTRIBUTION STATEMENT}

$\mathrm{MKH}$ designed the research experiment \& conception. MRI collected, processed the plant material. MRI, NMP and JN carried out the laboratory work. Data analysis and interpretation were aided by the MRI, MGU and SRA. MGU and MRI made the indispensable corrections in the write-up and critically revised the manuscript, gave final endorsement for the submission of a revised version. Finally, all authors read the final version and gave their confirmation to submit.

\section{COMPETING INTEREST STATEMENT}

All authors declare that they have no competing interests.

\section{ETHICS CONSIDERATION}

All authors hereby declare that "Principle of laboratory animal care" (NIH publication No. 85-23, revised 1985) were followed, as well as specific national laws where applicable. All proposed research protocols have been examined and approved by the Ethical Committee of the University of Chittagong, Bangladesh under the approval no- cc98056.

\section{FUNDING STATEMENT}

None.

\section{ADDITIONAL INFORMATION'S}

No additional information is available for this paper.

\section{REFERENCES}

[1] Ibrahim M, Baura J, Islam T, Homa Z, Chowdhury MMU, Hossain MA, et al. Preliminary Phytochemical and Pharmacological Investigations of Alpinia conchigera Griff. and Plumbago indica L. Bangladesh Pharm J 2012; 15(2): 153-7.

https://doi.org/10.3329/bpj.v15i2.12581

[2] Mohammadi S, Jafari $B$, Asgharian $P$, Martorell $M$, Sharifi-Rad J. Medicinal plants used in the treatment of Malaria: A key emphasis to Artemisia, Cinchona, Cryptolepis, and Tabebuia genera. Phytother Res 2020.

[3] Penso G. Inventory of medicinal plants used in the different countries: Organisation Mondiale de la Santé; 1978.

[4] Thapar N, Sanderson IR. Diarrhoea in children: an interface between developing and developed countries. Lancet 2004; 363(9409): 641-53.

https://doi.org/10.1016/S0140-6736(04)15599-2

[5] Liu L, Oza S, Hogan D, Chu Y, Perin J, Zhu J, et al. Global, regional, and national causes of under-5 mortality in 2000-15: an updated systematic analysis with implications for the Sustainable Development Goals. Lancet 2016; 388(10063): 3027-35.

https://doi.org/10.1016/S0140-6736(16)31593-8 
[6] Ashrafudoulla M, Bellah SF, Alam F, Faisal SS, Kafi MAH, Fuad F. Phytochemical screening of Solanum nigrum L, S. myriacanthus Dunal, Solanum melongena and Averrhoa bilimbi in Bangladesh. J Med Plants 2016; 4(1): 35-8.

[7] Abebe D. The role of medicinal plants in health care coverage of Ethiopia: the possible benefits of integration. 2001. In: Zewdu M, editor. Conservation and sustainable use of medicinal plants in Ethiopia, Proceedings of the National workshop, 28 April - 01 May 1998. Addis Ababa. Edited by , Demissie A: Institute of Biodiversity Conservation and Research; 2001. pp. 6-21

[8] Mekelle E. Traditional medicinal plants used by people in Libo-Kemkem district, south Gondar, Ethiopia. Asian J Agric Sci 2012; 4(3): 171-6.

[9] Bellah S, Islam K, Karim M, Hossain M, Ashrafudoulla M, Hasan M. Phytochemical and Pharmacological Screening of the fruits of Lagerstroemia speciosa (L.) pers. World J Pharm Sci 2016; 4(5): 205-11.

[10] Miliauskas G, Venskutonis P, Van Beek T. Screening of radical scavenging activity of some medicinal and aromatic plant extracts. Food Chem 2004; 85(2): 231-7.

https://doi.org/10.1016/j.foodchem.2003.05.007

[11] King A, Young G. Characteristics and occurrence of phenolic phytochemicals. J Am Diet Assoc 1999; 99(2): 213-8. https://doi.org/10.1016/S0002-8223(99)00051-6

[12] Balasundram N, Sundram K, Samman S. Phenolic compounds in plants and agri-industrial by-products: Antioxidant activity, occurrence, and potential uses. Food Chem 2006; 99(1): 191-203.

https://doi.org/10.1016/j.foodchem.2005.07.042

[13] Soberón JR, Sgariglia MA, Sampietro DA, Quiroga EN, Vattuone MA. Free radical scavenging activities and inhibition of inflammatory enzymes of phenolics isolated from Tripodanthus acutifolius. J Ethnopharmacol 2010; 130(2): 329-33.

https://doi.org/10.1016/j.jep.2010.05.015

[14] Auddy B, Ferreira M, Blasina F, Lafon L, Arredondo F, Dajas $F$, et al. Screening of antioxidant activity of three Indian medicinal plants, traditionally used for the management of neurodegenerative diseases. J Ethnopharmacol 2003; 84(23): $131-8$ https://doi.org/10.1016/S0378-8741(02)00322-7

[15] Koo H-J, Lim K-H, Jung H-J, Park E-H. Anti-inflammatory evaluation of gardenia extract, geniposide and genipin. J Ethnopharmacol 2006; 103(3): 496-500.

https://doi.org/10.1016/j.jep.2005.08.011

[16] Kim J-Y, Shim SH. Medicinal Herbs Effective Against Atherosclerosis: Classification According to Mechanism of Action. Biomol Ther 2019; 27(3): 254. https://doi.org/10.4062/biomolther.2018.231

[17] Orekhov AN, Ivanova EA. Cellular models of atherosclerosis and their implication for testing natural substances with antiatherosclerotic potential. Phytomedicine 2016; 23(11): 11907.

https://doi.org/10.1016/j.phymed.2016.01.003

[18] Tuncer MA, Yaymaci B, Sati L, Cayli S, Acar G, Altug T, et al. Influence of Tribulus terrestris extract on lipid profile and endothelial structure in developing atherosclerotic lesions in the aorta of rabbits on a high-cholesterol diet. Acta Histochem 2009; 111(6): 488-500.

https://doi.org/10.1016/j.acthis.2008.06.004

[19] Hussain F. In vitro thrombolytic potential of root extracts of four medicinal plants available in Bangladesh. Anc Sci Life 2014; 33(3): 162. https://doi.org/10.4103/0257-7941.144620

[20] Tandon V, Pal P, Roy B, Rao H, Reddy K. In vitro anthelmintic activity of root-tuber extract of Flemingia vestita, an indigenous plant in Shillong, India. Parasitol Res 1997; 83(5): 492-8.

https://doi.org/10.1007/s004360050286
[21] Kobayashi H, de Mejía E. The genus Ardisia: a novel source of health-promoting compounds and phytopharmaceuticals. J Ethnopharmacol 2005; 96(3): 347-54. https://doi.org/10.1016/j.jep.2004.09.037

[22] Islam MR, Naima J, Proma NM, Hussain MS, Uddin SN, Hossain MK. In vivo and in-vitro evaluation of pharmacological activities of Ardisia solanacea leaf extract. Clin Phytoscience 2019; 5(1): 32. https://doi.org/10.1186/s40816-019-0128-9

[23] Evans WC. Trease and Evans Pharmacognosy, International Edition E-Book: Elsevier Health Sciences; 2009 May 27.

[24] Tiwari P, Kumar B, Kaur M, Kaur G, Kaur H. Phytochemical screening and extraction: a review. Int Pharm Sci 2011; 1(1): 98-106.

[25] Al-Araby S, Rahman MA, Chowdhury MA, Das $R$, Chowdhury T, Hasan CMM, et al. Padina tenuis (marine alga) attenuates oxidative stress and streptozotocin-induced type 2 diabetic indices in Wistar albino rats. S Afr J Bot 2020; 128: $87-100$.

https://doi.org/10.1016/j.sajb.2019.09.007

[26] Oecd. OECD Guidelines for the Testing of Chemicals: Organization for Economic; 1994. http://www.oecd.org/ chemicalsafety/testing/oecdguidelinesforthetestingofchemical s.htm. (acceseed August 15, 2020)

[27] Hackam DG, Anand SS. Emerging risk factors for atherosclerotic vascular disease: a critical review of the evidence. Jama 2003; 290(7): 932-40. https://doi.org/10.1001/jama.290.7.932

[28] Zaoui A, Cherrah $\mathrm{Y}$, Mahassini N, Alaoui K, Amarouch $\mathrm{H}$, Hassar M. Acute and chronic toxicity of Nigella sativa fixed oil. Phytomedicine 2002; 9(1): 69-74. https://doi.org/10.1078/0944-7113-00084

[29] Shoba FG, Thomas M. Study of antidiarrhoeal activity of four medicinal plants in castor-oil induced diarrhoea. J Ethnopharmacol 2001; 76(1): 73-6. https://doi.org/10.1016/S0378-8741(00)00379-2

[30] Sanja S, Sheth N, Patel N, Dhaval P, Biraju P, PATEL D, et al. Characterization and evaluation of antioxidant activity of Portulaca oleracea. Int. J. Pharm. Pharm. Sci 2009; 1: 74-84.

[31] Pandey MM, Govindarajan R, Rawat AKS, Pushpangadan P. Free radical scavenging potential of Saussarea costus. Acta Pharm 2005; 55(3): 297.

[32] Srinivasan R, Chandrasekar M, Nanjan M, Suresh B. Antioxidant activity of Caesalpinia digyna root. $J$ Ethnopharmacol 2007; 113(2): 284-91 https://doi.org/10.1016/j.jep.2007.06.006

[33] Reddy BS, Reddy RKK, Reddy BP, Ramakrishna S, Diwan PV. Potential in vitro antioxidant and protective effects of Soymida febrifuga on ethanol induced oxidative damage in HepG2 cells. Food Chem Toxicol 2008; 46(11): 3429-42. https://doi.org/10.1016/j.fct.2008.08.034

[34] Mohammad Shah Hafez K, Md. Sofi M, Nishan C, Shabbir A Md. Abdullah Al M, Md. Akramul H, et al. Antithrombotic and cytotoxic activities of four Bangladeshi plants and PASS prediction of their isolated compounds. J Basic Clin Physiol Pharmacol 2016; 27(6): 659-66.

https://doi.org/10.1515/jbcpp-2015-0144

[35] Prasad S, Kashyap RS, Deopujari JY, Purohit HJ, Taori GM, Daginawala HF. Development of an in vitro model to study clot lysis activity of thrombolytic drugs. Thromb J 2006; 4(1): 14 https://doi.org/10.1186/1477-9560-4-14

[36] Ajaiyeoba E, Onocha P, Olarenwaju O. In vitro anthelmintic properties of Buchholzia coriaceae and Gynandropsis gynandra extracts. Pharm Biol 2001; 39(3): 217-20. https://doi.org/10.1076/phbi.39.3.217.5936

[37] Auletta CS, RAC M. Acute, subchronic, and chronic toxicology. Handbook of Toxicology, Second Edition: CRC Press; 2001. pp. 82-3. https://doi.org/10.1201/9781420042078.ch2 
[38] Islam AMT, Uddin ME, Chowdhury MAU, Rahman MM, Habib MR, Rahman MA. In vivo antidiarrheal and cytotoxic potential of different fractions of Pandanus Foetidus leaves. Am J Biomed Sci 2013; 5(3): 208-16. https://doi.org/10.5099/aj130300208

[39] Niemegeers C, Awouters F, Janssen P. The castor oil test in rats: an in vivo method to evaluate antipropulsive and antisecretory activity of antidiarrheals? Drug Dev Res 1984; 4(2): 223-7. https://doi.org/10.1002/ddr.430040211

[40] Sisay M, Engidawork E, Shibeshi W. Evaluation of the antidiarrheal activity of the leaf extracts of Myrtus communis Linn (Myrtaceae) in mice model. BMC Complement Altern Med 2017; 17(1): 103. https://doi.org/10.1186/s12906-017-1625-3

[41] Shiferie F, Shibeshi W. In vivo antidiarrheal and ex-vivo spasmolytic activities of the aqueous extract of the roots of Echinops kebericho Mesfin (Asteraceae) in rodents and isolated Guinea-pig ileum. Int J Pharm Pharmacol 2013; 2: 110-6.

[42] Umer S, Tekewe A, Kebede N. Antidiarrhoeal and antimicrobial activity of Calpurnia aurea leaf extract. BMC Complement Altern Med 2013; 13(1): 21. https://doi.org/10.1186/1472-6882-13-21

[43] Palombo EA. Phytochemicals from traditional medicinal plants used in the treatment of diarrhoea: modes of action and effects on intestinal function. Phytother Res 2006; 20(9): 717-24. https://doi.org/10.1002/ptr.1907

[44] Meir S, Kanner J, Akiri B, Philosoph-Hadas S. Determination and involvement of aqueous reducing compounds in oxidative defense systems of various senescing leaves. J Agric Food Chem 1995; 43(7): 1813-9. https://doi.org/10.1021/jf00055a012

[45] Roy A, Khanra K, Mishra A, Bhattacharyya N. General analysis and antioxidant study of traditional fermented drink Handia, its concentrate and volatiles. Adv Life Sci Appl 2012; 1(3): 54-7.

[46] Chung Y-C, Chang C-T, Chao W-W, Lin C-F, Chou S-T. Antioxidative activity and safety of the 50 ethanolic extract from red bean fermented by Bacillus subtilis IMR-NK1. J Agric Food Chem 2002; 50(8): 2454-8. https://doi.org/10.1021/jf011369q
[47] Chew AL, Jessica JJA, Sasidharan S. Antioxidant and antibacterial activity of different parts of Leucas aspera. Asian Pac J Trop Biomed 2012; 2(3): 176-80. https://doi.org/10.1016/S2221-1691(12)60037-9

[48] Hagerman AE, Riedl KM, Jones GA, Sovik KN, Ritchard NT, Hartzfeld PW, et al. High molecular weight plant polyphenolics (tannins) as biological antioxidants. J Agric Food Chem 1998; 46(5): 1887-92. https://doi.org/10.1021/jf970975b

[49] Shirwaikar A, Shirwaikar A, Punitha I. Antioxidant studies on the methanol stem extract of Coscinium fenestratum. Nat Prod Res 2007; 13(1): 40-5.

[50] Islam AMT, Chowdhury MAU, Uddin ME, Rahman MM, Habib MR, Uddin MGM, et al. Protective effect of methanolic extract of Hylocereus polyrhizus fruits on carbon tetra chloride-induced hepatotoxicity in rat. European J Med Plants 2013; 500-7. https://doi.org/10.9734/EJMP/2013/5090

[51] Sahreen S, Khan MR, Khan RA. Evaluation of antioxidant activities of various solvent extracts of Carissa opaca fruits. Food Chem 2010; 122(4): 1205-11.

https://doi.org/10.1016/j.foodchem.2010.03.120

[52] Etuk E, Agaie B, Ladan M, Garba I. The modulatory effect of Cochlospermum tinctorium a rich aqueous root extract on liver damage induced by carbon tetrachloride in rats. Afr $J$ Pharm Pharmacol 2009; 3(4): 151-7.

[53] Parry MA, Zhang XC, Bode W. Molecular mechanisms of plasminogen activation: bacterial cofactors provide clues. Trends Biochem Sci 2000; 25(2): 53-9. https://doi.org/10.1016/S0968-0004(99)01521-2

[54] Collen D. Coronary thrombolysis: streptokinase or recombinant tissue-type plasminogen activator? Ann Intern Med 1990; 112(7): 529-38.

https://doi.org/10.7326/0003-4819-112-7-529

[55] Mahmud S, Akhter S, Rahman M, Aklima J, Akhter S, Merry $\mathrm{SR}$, et al. Antithrombotic effects of five organic extracts of Bangladeshi plants in vitro and mechanisms in in silico models. Evid Based Complement Alternat Med 2015; 2015: 782742. https://doi.org/10.1155/2015/782742

[56] Aziz A, Raju GS, Das A, Ahmed J, Moghal MMR. Evaluation of in vitro anthelmintic activity, total phenolic content and cytotoxic activity of Crinum latifolium L.(Family: Amaryllidaceae). Adv Pharm Bull 2014; 4(1): 15.

\section{DOI: https://doi.org/10.29169/1927-5951.2020.10.05.17}

(C) 2020 Islam et al.; Licensee SET Publisher.

This is an open access article licensed under the terms of the Creative Commons Attribution Non-Commercial License (http://creativecommons.org/licenses/by-nc/3.0/) which permits unrestricted, non-commercial use, distribution and reproduction in any medium, provided the work is properly cited. 